\title{
MARITAL STATUS AND SUBJECTIVE WELL-BEING: DOES EDUCATION LEVEL TAKE INTO ACCOUNT?
}

\author{
Edmond Ndayambaje ${ }^{1,2, *}$, Adi Cilik Pierewan ${ }^{2}$, Emmanuel Nizeyumukiza $^{1}$, \\ Balthazar Nkundimana ${ }^{3}$, Yulia Ayriza ${ }^{2}$ \\ ${ }^{1}$ University of Rwanda, Rwanda, ${ }^{2}$ Universitas Negeri Yogyakarta, Indonesia, \\ ${ }^{3}$ Chongqing Medical University, China \\ *e-mail: edmond.ndayambaje@gmail.com
}

\begin{abstract}
Following western trends besides several Asian countries, Indonesian families are experiencing an increase number of single men and women which seems to ignore traditional standards ages of getting married for both gentlemen and ladies. Indonesian youth in this category are subjected to social pressure to marry, and this affect their subjective well-being. Using data from Indonesian Family Life Survey (IFLS) 2014; $5^{\text {th }}$ wave with 29,160 participants $(15.581$ women and 13.579 men) from 15,160 households and 297 Districts, this study was aimed at studying how marital status and subjective well-being are related in Indonesia, and how education take into account. Linear regression was performed to calculate the estimation correlation. After controlling confounding variables, the results show that married people are happier than singles, divorced, and widowers. In educational field, the research findings revealed that highly educated people are happier and satisfied than those who are less educated. Based on the results of this study, governments, policymakers, and their stakeholders need to encourage people to be engaged in education so that they rise their happiness. Further research orientations and recommendations were discussed for future researchers and policymakers to improve people's well-being.
\end{abstract}

Keywords: education, happiness, Indonesia, marital status, subjective well-being

\section{STATUS PERKAWINAN DAN KESEJAHTERAAN SUBJEKTIF: APAKAH TINGKAT PENDIDIKAN BERPERAN?}

\begin{abstract}
Abstrak: Mengikuti tren Barat dan beberapa negara Asia, keluarga Indonesia mengalami peningkatan jumlah pria dan wanita lajang yang tampaknya mengabaikan standar tradisional tentang usia menikah untuk pria dan wanita. Anak-anak muda Indonesia dalam kategori ini menjadi sasaran tekanan sosial untuk menikah dan ini memengaruhi kesejahteraan subjektif mereka. Dengan menggunakan data dari Indonesian Family Life Survey (IFLS) 2014; $5^{\text {th }}$ wave dengan 29.160 peserta (15.581 perempuan dan 13.579 laki-laki) berasal dari 15.160 rumah tangga dan 297 kabupaten, penelitian ini bertujuan untuk meneliti bagaimana hubungan antara status perkawinan dan kesejahteraan subjektif di Indonesia dan bagaimana peran tingkat pendidikan dalam hubungan tersebut. Regresi linier dilakukan untuk menghitung korelasi estimasi. Setelah mengendalikan variabel pengganggu, hasil menunjukkan bahwa orang yang menikah lebih bahagia daripada yang lajang, yang bercerai, janda dan duda. Di bidang pendidikan, temuan penelitian mengungkapkan bahwa orang-orang dengan tingkat pendidikan tinggi lebih bahagia daripada mereka yang tingkat pendidikanannya rendah. Berdasarkan hasil penelitian ini, pemerintah, para pembuat kebijakan dan pemangku kepentingan perlu mendorong orang untuk menempuh pendidikan yang tinggi dalam rangka untuk meningkatkan kebahagiaan mereka. Orientasi dan rekomendasi untuk penelitian yang akan datang dibahas bagi para peneliti dan pembuat kebijakan di masa mendatang dalam rangka untuk meningkatkan kesejahteraan masyarakat.
\end{abstract}

\section{Kata Kunci: pendidikan, kebahagiaan, Indonesia, status perkawinan, kesejahteraan subjektif}

\section{INTRODUCTION}

Several studies have shown that marital status affects people's subjective well-being (Bambling, Edirippulige, \& Himawan, 2018; Himawan, 2018; Himawan, Bambling, \&
Edirippulige, 2017), where for instance the researchers reported that married people are happier than unmarried ones (Anusic, Yap, \& Lucas, 2014; Greenstein, 2016; Khodarahimi, 2015; Yap, Anusic, \& Lucas, 2012). Other 
studies identified subjective well-being (SWB) as an effect of income, and they show the mutual relationship between those two variables (Guo, Baruch, \& Russo, 2017; Hudson, 2006), where they find out that income has positively affected people's happiness. On the other hand, others mentioned the importance of our level of education in moderating people's happiness (Cheung \& Chan, 2009; Michalos, 2017; Striessnig, 2015). Said differently, people's subjective well-being or happiness must be affected by their marital status (either being married or unmarried), income, but also their education level which enables them to get whatever they need in life.

Besides the contribution of educational level in improving people's well-being, high educated individuals intend to be respected in a society where they live. Hudson (2006), said that education makes people be "open-minded", and because of that they become able to get new ideas, try new projects, and this enables them to be respected in most institutions or communities in general. In other words, "the more people are higher educated, the better they are much respected in society, and this can increase their happiness". Guo et al. (2017) stated that income generates more happiness. As it is known, being unemployed or getting less income can affect subjective well-being (Andersen, 2009; Diener, 2012; Winkelmann \& Winkelmann, 1998). From this statement, it is to say that the more people are higher educated, they earn much money from their good jobs or projects, which helps them to move from one step of life to another (for example: getting married), and this can increase their happiness. Said differently, education, income, employment, and marital status have effects on people's subjective well-being as confirmed by (Hudson, 2006).

Generally, marriage is considered to be a significant predictor of well-being and provides emotional, social and economic supports between married couples, which increases their happiness. It also might be considered as an appropriate way of exercising both personal and social status (Greenstein, 2016; Himawan, 2018). On contrast, singleness might decrease happiness for those who are not yet married. According to BPS (2018b), nowadays, the number of adult single people is increasing in Indonesia compared to the last forty years. Indonesian society and its culture consider marriage as a full adult's status, attributes some stereotypes on single adults people, discriminate against them which affects their happiness (Situmorang, 2007; Retnaningsih, 2013; Himawan et al., 2017). In other words, it can be said that due to the discrimination and stereotypes faced by single people in Indonesia, not yet married people are less happy than married ones.

The increasing number of single adult people is seen in different societies worldwide. For instance, according to the US Census Bureau (2016) in the United States of America, over 50 percent of the married people end up divorcing, by contrast, in the last 20 years has decreased. This doesn't mean that whatever marriage quality has been improved but people preferred to delay the marriage age and another number increased in cohabitation. Also according to (OECD, 2018) in most of its countries the quantity of marriage was between 7-10 per 1000 people in 1970, and since 1995 decreased to $5-7$ per 1000 people, and nowadays quantity of marriage in numbers is continue to decrease since that time. This case also seen in European countries (Corselli-Nordblad \& Gereoffy, 2015), Australia (Australian Bureau of Statistics, 2016), and in some Asian countries include Indonesia (Bambling et al., 2018; Himawan et al., 2017; Himawan, Bambling, \& Edirippulige, 2018), where marriage was considered as norm for adults, now it is regarded as less necessary.

Regardless of the rising proportion of unmarried people all over the world, a lot of studies marked a noticeable difference between western and Asian societies, taking account of singleness and marriage. Generally in western society marriage seems to be a personal choice, which is different from the case of Asian countries including Indonesia, that still have the universal meaning of marriage, where single adults are socially pushed to get married (Himawan, 2018). Even though the number of not yet married people has been increased, in the country above (Indonesia), as it has been proved by BPS (2018b) the contribution of modernization and globalization cannot be negligible, and consequently, it is considered a barrier to the conservation of Indonesian traditional values (Himawan et al., 2017). On the other side, it can have negative effects on Indonesian society in general, in terms of happiness. 
Following western phenomenon of singlehood in western society and some as Asian countries, in Indonesia also the problem is not new, as it was revealed by (Robards, Evandrou, Falkingham, \& Vlachantoni, 2012; Greenstein, 2016; Richmond \& Roehner, 2016; Sujarwoto, Tampubolon, \& Pierewan, 2017; Himawan, 2018; Rosifah, Nuryakin, \& Handalusia, 2019). Based on the relationship of those three variables, this study examined the association between marital status and subjective wellbeing, and how educational level can take into account. From the findings of this study, some measures should be taken to increase happiness of Indonesian people, by removing some barriers that are preventing young adults for not being married, to break the social stigma that they are facing as it has been found by (Himawan et al., 2017; Retnaningsih, 2013; Situmorang, 2007). Moreover, they will enable educational institutions, and policymakers to take some measures and to encourage their citizens to study at a high level, to get good jobs and earn much money which enables them to be fully happy.

\section{METHODS}

\section{Participants and procedure}

In the present study, we used data from the Indonesian Family Life Survey (IFLS), $5^{\text {th }}$ wave which took place in 2014-2015. IFLS is a longitudinal socio-economic and health survey representing around $80 \%$ of the entire Indonesian population (Strauss, Witoelar, \& Sikoki, 2016). It provides data information on individuals, their families, households, communities, education besides health services that they use. The IFLS (2014) $5^{\text {th }}$ wave used 29.160 people living in 13 provinces of Indonesia, recruited from 16, 204 households. The self-reported questionnaires and interviews were used to collect the data and the participation rate was $92 \%$, Strauss et al. (2016).

\section{Measures}

For marital status used two of its categories namely married and unmarried. During this analysis, we coded (1) for married and (0) for unmarried (single, widowed and divorced). One question for both happiness and life satisfaction has been used to measure SWB. For life satisfaction, the respondents were supposed to answer the one question asking them about "how they are satisfied with life as a whole? While for happiness, the question was about "how they are happy they are in nowadays" Life satisfaction was measured using scale of life satisfaction by Ayriza, Setiawati, Nurhayati, \& Gumelar (2019) rated from $1=$ "not at all satisfied" to $5=$ "completely satisfied" whereas happiness rated from 1 = "very unhappy" to $4=$ "very happy" and both of them by Diener, Emmons, Larsen, \& Griffin (1985). Educational level affects SWB (Kuroki, 2011). Education was coded based on the educational level attained by respondents; (1) for kindergarten, (2) for elementary school and equivalents, (3) for junior high school and equivalents, (4) for senior high school and equivalents and (5) for high education.

\section{Control variables}

Marital status is seen as an independent variable the concerned study since it is composed of married and unmarried (Single, widowed, divorced) Indonesian adults. The same with education. On the other hand, subjective wellbeing is a dependant variable composed of both happiness and life satisfaction (Diener et al., 1985; Veenhoven, 2009). Out of those three main variables, the researchers also added other covariates as gender, extraversion personality trait, age, unemployment, smoking behaviours, religiosity, physical health, depression, and social trust, to investigate their correlation with marital status, education, and subjective wellbeing. Therefore, the intention was to control them as the potential confounders of the relations existing between marital status, education, and subjective well-being.

Gender is coded with dummy variable (1) for females and (0) for males. Marital status is coded as follows (1) for married and (0) for unmarried (single, widowed and divorced). Regarding unemployment, the working group was taken as categorical reference and was coded $(0)$, and those searching jobs and housekeepers were taken as unemployed and were coded (1). Smoking was coded (1) was entered for yes and (0) for no. Age can be a predictor of subjective well-being, and the age range was from 18-90 years old. Dummy codes for health were (1) for those who reported being more healthy, and (0) for those who answered to be somewhat healthy and very unhealthy. Extraversion personality trait was measured by two items rated from $1=$ 
disagree strongly, $5=$ agree strongly. Social trust was measured as follows 1 = very unlikely and $4=$ very likely. The two categories of religiosity were made and given dummy codes (1) for religious and (0) for not religious. Mental health was measured using the Center for Epidemiologic Studies Depression Scale, the short version with 10 items (Andresen, Malmgren, Carter, \& Patrick, 1994).

\section{RESULTS AND DISCUSSION Descriptive statistics}

From Table 1 and Table 2, it can be seen that the mean age of the sample is $38.9(\mathrm{SD}=1.07$, range $=18-90)$. Forty-seven percent reported being male while fifty-three reported female.

Table 1. Descriptive Statistics of the Sample for Categorical Variables

\begin{tabular}{lcc}
\hline & Percent & $\mathbf{N}$ \\
\hline Gender & & 29,122 \\
Male & 47 & 13,571 \\
Female & 53 & 15,551 \\
Education & & 23,363 \\
Elementary school & 37.6 & 8,785 \\
Junior high school & 23.4 & 5,458 \\
Senior high school & 34.1 & 7,974 \\
High education & 4.9 & 1,146 \\
Marital status & & 29,147 \\
Married & 78 & 22,704 \\
Unmarried & 22 & 6,443 \\
Religiosity & & 24,319 \\
Religious & 72.88 & 17,723 \\
Not religious & 27.12 & 6,596 \\
Smoking behaviours & & 10,921 \\
Smoking & 95.66 & 10,447 \\
Non-smoking & 4.34 & 474 \\
Self-Rated Health & & 29,154 \\
Healthy & 78.29 & 22,826 \\
Unhealthy & 21.71 & 6,328 \\
Employment & & 29.064 \\
Employed & 70.52 & 20,496 \\
Unemployed & 29.48 & 8,568 \\
\hline
\end{tabular}

Moderately, $37.6 \%$ finished elementary school, $23.4 \%$ junior high school, $34.1 \%$ senior high school and $4.9 \%$ finished high education. $22 \%$ of the respondents reported being unmarried while the rest $(78 \%)$ reported being married. Around three fourth of the respondents reported that they are religious and healthy while around one fourth reported not being religious and unhealthy. Over 95\% reported that they smoke while 5\% report that they don't smoke. Around three fourth of the respondent reported that they are employed while one fourth reported that they are jobless.

Table 2. Descriptive Statistics of the Sample for Continuous Variables

\begin{tabular}{lccccc}
\hline & Min & Max & Mean & SD & NA's \\
\hline Life satisfaction & 1 & 5 & 3.31 & 0.8 & 6 \\
Happiness & 1 & 4 & 3.03 & 0.5 & 6 \\
Social trust & 1 & 4 & 2.88 & 1.07 & 513 \\
Age & 18 & 90 & 38.98 & 14.17 & 6 \\
Extraversion & 2 & 10 & 7.18 & 1.32 & 6 \\
Depression & 0 & 30 & 6.33 & 4.7 & 7 \\
\hline
\end{tabular}

The mean score is $3.31(\mathrm{SD}=.8$, range $=$ $1-5)$ for life satisfaction, $3.03(\mathrm{SD}=.5$, range $=1-4)$ for happiness, $2.88(\mathrm{SD}=1.07$, range $=$ $1-4)$ for social trust, $7.18(\mathrm{SD}=1.32$, range $=$ 2-10) for extraversion and $6.33(\mathrm{SD}=4.7$, range $=0-30$ ) for depression.

\section{Multivariate Analysis}

In table 3, it can be found the results of multivariate analysis with a range of covariates for happiness and life satisfaction. The results show that the personality traits of separation are largely related to happiness and life satisfaction, respectively $(\beta=.02, p$-value $<.001)$, and life satisfaction $(\beta=.016, p$-value $<.05)$.

Table 3. Results of Linear Regressions on Happiness and Life Satisfaction

\begin{tabular}{lcccc}
\hline & \multicolumn{2}{c}{ Happiness } & \multicolumn{2}{c}{ Life satisfaction } \\
\cline { 2 - 5 } & Estimates & SE & Estimates & SE \\
\hline Intercept & $2.95^{* * *}$ & .05 & $3.02 * * *$ & .09 \\
Single & $-.14^{* * *}$ & .01 & .03 & .02 \\
Divorced & $-.33^{* * *}$ & .03 & $-.20^{* * *}$ & .05 \\
Widowed & $-.14^{* * *}$ & .03 & .04 & .05 \\
Extraversion & $.02 * * *$ & .004 & $.016^{*}$ & .007 \\
Gender (male) & .01 & .02 & .05 & .04 \\
Age & $-.00^{* * *}$ & .00 & $-.00^{* * *}$ & .00 \\
Junior HS & .02 & .01 & .03 & .02 \\
Senior HS & $.07 * * *$ & .01 & $.06^{* *}$ & .02 \\
High edu & $.11^{* * *}$ & .03 & $.11^{*}$ & .05 \\
Smoking & .02 & .03 & .02 & .05 \\
Social trust & $.01 * *$ & .00 & $.03 * * *$ & .00 \\
\hline
\end{tabular}




\begin{tabular}{lcccc}
\hline & \multicolumn{2}{c}{ Happiness } & \multicolumn{2}{c}{ Life satisfaction } \\
\cline { 2 - 5 } & Estimates & SE & Estimates & SE \\
\hline Health & $.09 * * *$ & .01 & $.18^{* * *}$ & .02 \\
Unemployment & .00 & .01 & .00 & .02 \\
Religious & $.04 * * *$ & .01 & $.13 * * *$ & .02 \\
Depression & $-.02 * * *$ & .00 & $-.02 * * *$ & .00 \\
\hline Notes $: * \alpha<5 \%, * * \alpha<1 \%, * * * \alpha<0.1 \%$ &
\end{tabular}

After controlling all variables, it is seen that they are all associated with people's happiness and the level of their life satisfaction. Nevertheless, it is seen that men are not happy compared to women because women are happier than men $(\beta=-.01, p$-value $>.05)$, and they are less satisfied than women even if the difference is noteworthy $(\beta=-0.05, p$-value $>.05)$. It has also seen that age is negatively correlated with both happiness $(\beta=-0.005, p$-value $<.001)$ and life satisfaction $(\beta=-.004, p$-value $<.001)$, and the relationship are very significant. In positive way, education and happiness are absolutely ( $\beta=$ $.07, p$-value $<.001$ ), for senior high school; $\beta=$ $.11, p$-value $<.001$ ) for high education, and life satisfaction $(\beta=.06$, $p$-value $<.05)$, for senior high school, and $(\beta=.11, p$-value $<.05)$.

Regarding marital status, the results of this study presented that show unmarried people are not as happy as the married ones. In addition, a negative correlation for single people has been revealed in the present study $(\beta=-.14$, $p$-value $<.001),(\beta=-.33$, $p$-value $<.001)$, for separated or divorced, $(\beta=-.14, p$-value $<.001)$ for widowed. Moreover, in this study, it has been presented that the divorced people are less satisfied $(\beta=-.20, p$-value $<.01)$ than married people, moreover single people $(\beta=.03$, $p$-value $>.05)$, and widowers $(\beta=.04, p$-value $>.05)$ seem to be satisfied with their lives even if that association is not significant. The connection existing between smoking and happiness $(\beta=$ .02 , $p$-value $>.05)$ and life satisfaction $(\beta=.02$, $p$-value $>.05)$ is found positive even if it is not significant.

Social trust, life satisfaction, and happiness are said to be significantly correlated with $(\beta=$ .014 , $p$-value $<.001)$, and $(\beta=.036$, $p$-value $<$ $.001)$ respectively. Religiosity is found to have a high positive correlation with life satisfaction and happiness, $(\beta=.04, p$-value $<.001)$ for happiness and $(\beta=.13, p$-value $<.001)$ for life satisfaction.
This study has also revealed that being healthy has a significant correlation with both happiness and life satisfaction. The correlation is $(\beta=.09, p$-value $<.001)$ for happiness and $(\beta=$ $.18 p$-value $<.001)$ for life satisfaction. As it was predictable, depression is found to be harmfully correlated with both happiness $(\beta=-.02, p$-value $<.001)$ and life satisfaction $(\beta=-.02, p$-value $<$ .001) respectively.

\section{Discussion}

Using the data from IFLS $20145^{\text {th }}$ wave, this study investigated how subjective wellbeing and marital status are associated, and how education takes into account in Indonesia. As it is known marital status is recognized as a condition of being singles, married, divorced (separated), widowed, or cohabitating with someone in terms of relations between wife and husband and expressed in a wide term of marriage (Alberta Human Rights Commission, 2017; Greenstein, 2016; Richmond \& Roehner, 2016). In terms of happiness, the findings of this study show that single and widowed are negatively correlated with happiness, on the other side, it revealed that the divorce is significantly negative correlated to both happiness and life satisfaction. In other words, the results of the present research show that unmarried people (single, divorced and widowed) are said to be less happy and satisfied than those who are married.

Furthermore, the results approve other previous related studies carried out by Khodarahimi (2015) which affirm that married people experience a significant level of happiness than those who are widowed, divorced, and single. Findings of this study, replicate the Yap et al. (2012) and Anusic et al. (2014)'s studies which show that in a long way, married people live happily compared to unmarried ones and as a result, they are satisfied with life rather than them. Also, the results of the present study are in the same line with the findings of Greenstein (2016) which shown that regardless gender, age, etc., in general, the married individuals experience sufficient happiness and because of that, they seem to like those who are satisfied with how they live compared to unmarried individuals. Additionally, females are said to feel happy and satisfied than males.

The findings of this study also support other previous studies that have found the same 
results. For instance, with their tendency to be happier than other categories of marital status like singles, cohabitating, widowed, and the divorced ones who tend to have lower level of life satisfaction, the married people have been reported to have a high level of life satisfaction as reported by (Diener, Suh, Lucas, \& Smith, 1999; Diener, Gohm, Suh, \& Oishi, 2000, Ha \& Kim, 2013). They are also in line with different studies carried out in Indonesia related to subjective well-being/happiness and marital status which have shown that married individuals are happy compared to unmarried ones (Himawan, 2018; Himawan et al., 2017, 2018), Indonesian married individuals seem to be happier than the single ones (Rosifah et al., 2019). Nonetheless, it is not only the case of Indonesia, but also the same all over the world, as it has been revealed in their different studies related to subjective well-being and marital status (Veenhoven, 2006; Yap et al., 2012; Anusic et al., 2014; Greenstein, 2016; Lucas, 2018).

Different studies argued that generally married individuals are intended to be happier than unmarried people (Anusic et al., 2014; Greenstein, 2016; Himawan, 2018; Richmond \& Roehner, 2017; Robards et al., 2012; Sujarwoto et al., 2017; Veenhoven, 2006; Yap et al., 2012), but women seem to have an extreme degree of subjective wellbeing than men (Greenstein, 2016; Veenhoven, 2015). The people who are married are said to be happy and satisfied with life rather than unmarried people. However, women are mostly happier and satisfied compared to men; but cohabitating females not as happy as males in terms of subjective wellbeing (Greenstein, 2016).

Marital status and SWB are associated with one another. For instance, Greenstein (2016) confirmed that individuals who have a high level of life satisfaction are those who are married people compared to unmarried ones (single, widowed, divorced or separated). Besides, the number of single people is reported on the act of suicide compared to married people. By improving people's well-being it is very important to strengthen the people who are good to predict human life durability. It is marital status itself which determines the level of mortality and health (Tatangelo, Mccabe, \& Szoeke, 2017). Being unmarried is a pseudo-indicator of being alone and this is known to enrich the poor health outcomes. Generally, the human being is a social creature whose relation is connected between himself (herself) with others. For that, this is why being married helps people to feel fully integrated into the social relationship and improving their health. Improving their health also helps them experience a high level of life satisfaction (Tatangelo et al., 2017).

Married individuals also intend to have high levels of SWB more than unmarried, as it has been found by (Diener et al., 2000; Stock, Okun, \& Witter, 1985; Khodarahimi, 2015; Veenhoven, 2016). In terms of being satisfied with life, good feelings, the welfares of getting married to those of living divorced or separated were found minor in communistic countries rather than capitalistic countries. Negative emotions, on the other hand, the advantages of living married compared to those of being divorced or separated were found minor in countries that have a high tolerance level of divorce (Diener et al., 2000). In sum, the correlation between marital status and SWB cannot be differentiated by gender, but also the associations between marital status and SWB are quite similar worldwide.

As has been confirmed by BPS (2018a), In Indonesia, the percentage of unmarried people is growing up nowadays compared to forties in previous years. For example, compared to the percentage of 1, 4 in 1970 and with $3.5 \%$, in 2000 , the total proportion of unmarried ladies between 35-39 years old increased to 3.8\%. Furthermore, the mean age for marriage was fixed at 22.3 for women and 25.7 for men in 2010, while it was at 19 years old for women and 23 for men in 1970, with an increase of 2.9 percent (Jones, Bunnell, \& Yeo, 2010). This indicates that the age delay on both genders can justify the reason why this time the proportion of single individuals is increasing (Himawan et al., 2017; Himawan, 2018).

Socially being a single adult is seen as socially deviant in Indonesia, where the number of unmarried people and delaying marriage is increasing following western society trends. For example, Himawan et al. (2017) have found that the consequences of modernization are unavoidable and they are challenging young Indonesian's people values toward marriage expectations and this leads them delaying it and influence some of them to remain singles. This also is a challenge in the conservation of social 
values, where single adults develop strategies for maintaining the strong tension toward marriage. This pressure between conservation of traditional social values and the delaying marriage of singles, oppose the meaning of marriage, hence, it seems to be a barrier in the conservation of social traditional and religious or rituals values (Himawan et al., 2017; 2018). From the results of this study, it is to say that the more the number of single adult people is increasing, it will have negative effects on Indonesian society, especially in terms of happiness.

Despite that social stigma and pressure to marry, Indonesian youth adults undergo harmful social and psychological effects, which may affect their happiness as it was confirmed by (Himawan et al., 2018). On the other side, different studies argued that unmarried people are said not to be. Also, it has been reported that the level of their life satisfaction is low compared to those who are married (Robards et al., 2012; Boyce, Wood, \& Ferguson, 2016; Hoorn, 2007), and this is the case of Indonesia. For instance, according to BPS (2018a) 76, 47 percent of married individuals are happy compared to 74 , 05 percent for singles people.

Regarding personality traits and SWB, in this study, the findings have proved that extraversion personality trait is significantly associated with life satisfaction and happiness. This confirms the results of (Harris, English, Harms, Gross, \& Jackson, 2017; Hoorn, 2007; Veenhoven, 2006) which revealed that extraverts report feeling happy and satisfied with life when compared to other categories of personality traits, specifically neuroticism. This has been emphasized by (Deneve, 1999; Diener et al., 1999; Veenhoven, 2016)'s studies which revealed that extraverted people are less depressed, and they express more their thankfulness than neurotic people. Finally, the findings of the current research replicate the one carried out by Sujarwoto et al. (2017), which have shown that extraversion personality trait is significantly connected to life satisfaction and happiness. In sum, it is to say that extraversion personality traits, especially is greater correlates with both happiness and life satisfaction, which means that it affects people's way of reacting towards events that happen to their daily life.

Further, the findings have revealed that males are less satisfied than females. This confirms the one carried out by Sujarwoto et al. (2017), which has found that men are less satisfied than women. It is also the same direction as Graham \& Soumya's (2012) study which discovered that generally those females are satisfied compared to males in the world. This can be caused by the difference in affecting factors that make them different too. For instance, most of the time men concentrate on the problem outside the domestic while women focus on their personal and family problems. This can justify why in Indonesia, women seem to be satisfied than men. In this study, the results show that age is negatively correlated with happiness and life satisfaction. This confirms what has been found by Stone, Schwartz, Broderick, \& Deaton, (2010)'s a study that age is the negative predictor of subjective well-being. In sum, it is to say Indonesia as a developing country, the more people are growing in age, the more they become more satisfied with life, and this affects their happiness, especially in their old age stage.

Findings show that religiosity is positively correlated to both happiness and life satisfaction, and that relationship is very significant on both sides. In other words, the present research discovered that religiosity has a valuable meaning to make people happy and feel satisfied with their life. This confirms other previous related studies of Lim \& Putnam (2010) that religious people are satisfied with their life than those who do not, because of religious services buildup the social network and relations. Sujarwoto et al. (2017) found that subjective happiness and life satisfaction are both benefited from personal religiosity community social interaction. Moreover, Okulicz-Kozaryn's (2010) research revealed social religiosity is positively related to life satisfaction than personal religiosity. In other words, the author found no correlation of believing in God and life satisfaction, but the author found a positive association of attending churches with the satisfaction of lives.

Regarding social trust, the results of the present study show a positive and strong connection between social trust and both life satisfaction and happiness. This confirms the one carried out by Kuroki (2011) which revealed that social trust seems to be significantly connected to people's happiness, and it positively affects social cohesion which enhances people to be happy and satisfied with lives. In other words, 
findings of this research has shown that the individuals who seem to be trustworthy are also satisfied with life and they are indeed happy compared to those who do not or who are neutral.

Surprisingly, the results of the current study show no correlation between unemployment with both life satisfaction and happiness. Our results oppose other related past studies of (Andersen, 2009; Diener, 2012; Winkelmann \& Winkelmann, 1998) who showed that unemployment has negative impacts on subjective well-being, where unemployed people were reported not to be happy and satisfied with conditions of their life. In other words, losing jobs and being unemployed have been seen negatively correlated with people's SWB, the results of the present research show no correlation of being unemployed with happiness and life satisfaction. Simultaneously, the results of the present study revealed no correlation between smoking with life satisfaction and happiness. These findings are in the same line with Churchill \& Farrell's (2017) study that being addicted to smoking can have a lower impact on happiness and (Weinhold \& Chaloupka, 2017)'s findings that stop smoking can positively affect people's SWB.

This study has also shown that being healthy is stronger correlated with both life satisfaction and happiness positively. This confirms a lot of studies done by Ngamaba, Panagioti, \& Armitage (2017) and Friedman \& Kern (2014) that being physically and psychologically healthy is correlated with people's SWB, individuals who have poor health have been reported to have poor subjective well-being. Moreover, married people have been reported to have good health compared to single people (Bulloch, Williams, Lavorato, \& Patten, 2017). It also supports the findings of (Jang, Kawachi, Chang, Boo, Shin, Lee, \& Cho, 2009)'s research which argues that married people are healthier than divorced, widowed, and single individuals, people who are already married have better health than unmarried ones (Robards et al., 2012; Greenstein, 2016). On the other side, the number of mortality in separated and single individuals is three times compared to individuals of the same age who are married (Richmond \& Roehner, 2017). In sum, it can be said that those individuals who are strongly healthy are happy and satisfied with their lives, but being married is additional to be healthier, happy and satisfied with life.
Not surprisingly, we found that depression is negatively correlated with happiness and life satisfaction, the strong depression is said to dominate men rather than women, and unmarried people (single, divorced and widowed) are said to be unhappier than those are already married in terms of depression. Our results confirm the one carried out by Bulloch et al. (2017) that married people are less depressed compared to unmarried. Additionally, the researchers argue that single females have depression compared to single men, but in general females experience depression than men. It also supports the results from the study of (Jang et al., 2009) that those individuals who already got married report are less depressed than divorced, widowed, and singe (not yet married) individuals.

Regarding education, the findings of this study show that education has a positive correlation with happiness and life satisfaction. These results approve other studies that have clearly shown the association of education level and people's subjective well-being. For instance, Cheung \& Chan's (2009) study showed that high satisfied individuals are found in developed countries, where the majority of their people are highly educated. Kristoffersen (2018) has found that people's high education is correlated with the satisfaction of their expectations, which raises their happiness. The findings of the study conducted by Striessnig (2015) on education, revealed that education has an indirect impact on people's life satisfaction through employment position, marital status, income, and prosperity, etc., which have an effect of their happiness in one way or another. Michalos's (2017) research has mentioned a positive connection existing between education level and happiness, it pointed out formal education at high-level leads facilitates people to obtain the degree or qualification that enables them to be obtain amazing and earn much money, were being satisfied with life.

The findings of this study confirm the statement which says that education positively affects people's happiness. For example, according to (Cheung \& Chan, 2009), people who are highly satisfied with life are seen in developed countries or nations where most of its people are highly educated. This allows them to be well-employed and get good salaries which increase their happiness. Similarly, in 
Hudson's (2006) study, the author has signalized the relationship between education level and people's life satisfaction, where educated people get more advantageous in life which increases their happiness. There is a high correlation between education level and life satisfaction expectations concerning life circumstances as living conditions, good housing, etc., which enables them feeling happy in terms of life satisfaction (Kristoffersen, 2018).

In most cases, education is said to be a predictor of socio-economic status and human capital in developing countries (including Indonesia), as confirmed by (Kuroki, 2011). Thus, it is seen that "the more people are higher educated, they increase chances to be well employed and get good salaries which enables them to improve their living conditions, satisfy their needs, and to accomplish some social status (example: getting married) all of them aimed at expanding the level of their happiness and life satisfaction, as long as they get whatever they expect to have in life. In sum, based on the findings of this study, it is to say that being married increase happiness and satisfaction with life, similarly high education level increase happiness too, due to that, it can be said that being married simultaneously with being highly educated makes people being happier and satisfied with lives.

\section{CONCLUSION}

As many Asian countries, Indonesia families are experiencing increasing number singlehood which is different from tradition standards ages for marriage. In Indonesia, young adults are socially under the pressure of getting married, and this affects their happiness. As it, known happiness and life satisfaction are the final goals of a human being's life. The results in the present study showed that married people are happier and satisfied than unmarried ones (single, divorced, and widowed). For that, if governments or nations and their stakeholders (religious, NGOs, etc.) need to maintain the happiness of their people, they should alleviate barriers that are preventing young adults from not being married or delaying their marriage. In sum, it is clear to say that the more people are married, the better they raise their level of happiness they also expand the level of life satisfaction. Similarly to education, the results of this study, significantly reveal that the percentage of highly educated people are less sufficient when considering the general population. For that, educational institutions and all of their shareholders including teachers and the decision-makers need to do all possible and encourage people to be highly educated which will enhance them to be well-employed and earn much money, aimed to increase their happiness and level of life satisfaction. Future studies should be conducted for investigating really what is causing youth adults to prefer not being married or to delay their marriage, and what should be done to numbers of highly educated people.

\section{ACKNOWLEDGMENTS}

In this study, the authors used secondary data from the Indonesia Family Life Survey $5^{\text {th }}$ wave conducted by RAND Corporation (http:// www.rand.org/labor/FLS/IFLS.html). We are grateful to RAND Corporation who provided free access to IFLS data and to the Indonesian people who participated in that survey.

\section{REFERENCES}

Alberta Human Rights Commission. (2017, November). Family status and marital status (Edmonton, Alberta T5J 4R7). https://www.albertahumanrights.ab.ca/ publications/bulletins_sheets_booklets/ sheets/protected_grounds/Pages/family_ and_marital_status.aspx.

Andersen, S. H. (2009). Unemployment and subjective well-being. Work and Occupations, 36(1), 3-25. doi: $10.1177 / 0730888408327131$.

Andresen, E. M., Malmgren, J. A., Carter, W. B., \& Patrick, D. L. (1994). Screening for depression in well older adults: evaluation of a short form of the CES-D (Center for Epidemiologic Studies Depression Scale). American Journal of Preventive Medicine, 10(2), 77-84.

Anusic, I., Yap, S. C. Y., \& Lucas, R. E. (2014). Does personality moderate reaction and adaptation to major life events? Analysis of life satisfaction and affect in an Australian national sample. Journal of Research in 
Personality, 51, 69-77. doi:10.1016/j. jrp.2014.04.009.

Australian Bureau of Statistics. (2016, 30 November). Marriage and divorce statistics Australia 2015. https://www. budgetdirect.com.au/blog/marriage-anddivorce-statistics-australia.html.

Ayriza, Y., Setiawati, F. A., Nurhayati, S. R., \& Gumelar, S. R. (2019). Does sleep quality serve as a mediator between well- being and academic achievement? Cakrawala Pendidikan, 38(1), 63-74. doi:10.21831/ cp.v38i1.22181.

BPS, Badan Pusat Statistik. (2018a, 15 August). Indonesian Happiness Index of 2017 (No.79/08/Th. XX). https://www.bps. go.id/.

BPS, Badan Pusat Statistik. (2018b). Statistik kesejahteraan rakyat welfare statistics 2018. https://bps.go.id/publication/201 8/11/26/81ede2d56698c07d510f6983/ statistik-kesejahteraan-rakyat-2018.html.

Bambling, M., Edirippulige, S., \& Himawan, K. K. (2018). The Asian single profiles: Discovering many faces of never married adults in Asia. Journal of Family Issues, 1-23. doi:10.1177/0192513X18789205.

Boyce, C. J., Wood, A. M., \& Ferguson, E. (2016). For better or for Worse: The moderating effects of personality on the marriage-life satisfaction link. Personality and Individual Differences, 97, 61-66. doi:10.1016/j.paid.2016.03.005.

Bulloch, A. G. M., Williams, J. V.A., Lavorato, D. H., \& Patten, S. B. (2017). The depression and marital status relationship is modified by both age and gender. Journal of Affective Disorders, 223(April), 65-68. doi:10.1016/j.jad.2017.06.007.

Cheung, Y. H., \& Chan, W. H. A. (2009). The effect of educationon life satisfaction accross countries. The Alberta Journal of Education Research, 55(1), 124-136. doi:10.1086/588220.
Churchill, S.A., \& Farrell,L.(2017). Investigating the relationship between smoking and subjective welfare. Journal of Behavioral and Experimental Economics, 71, 1-12. doi:10.1016/j.socec.2017.08.003.

Corselli-Nordblad, L., \& Gereoffy, A. (2015, June). Marriage and birth statistics: New ways of living together in the EU. https:// ec.europa.eu/eurostat/statistics-explained/ index.php?title=Marriage_and_birth statistics_-_new_ways_of_living together_in_the_EU\&oldid $=400392$.

Deneve, K. M. (1999). Happy as an extraverted clam? The role of personality for subjective well-being. Current Directions in Psychological Science, 8(5), 141-144. doi:10.1111/1467-8721.00033.

Diener, E. D., Gohm, C. L., Suh, E., \& Oishi, S. (2000). Similarity and the relations between marital status and subjective well-being across cultures. Journal of Cross-Cultural Psychology, 31(4), 419436. doi:10.1177/0022022100031004001.

Diener, E., Emmons, R. A., Larsen, R. J., \& Griffin, S. (1985). Satisfaction with life scale. Journal of Personality Assessment, 49, 71-75. doi:10.13072/midss.467.

Diener, E, Glatzer, W., Moum, T., Sprangers, A. G. M., Vogel, J., \& Veenhoven, R. (2009). The science of well-being. In P. E. Diener, E (Ed.), The science of well-being: The collected words of Ed Diener, Social Indicators Research Series 37. Champaign, IL: Springer Science+Business. doi:10.1007/978-90481-2350-6_1.

Diener, E. (2012). New findings and future directions for subjective well-being research. American Psychologist, 67(8), 590-597. doi: 10.1037/a0029541.

Diener, E., Suh, E. M., Lucas, R. E., \& Smith, H. L. (1999). Subjective weilbeing: Three decades of progress. Psychological Bulletin, 125(2), 276-302. doi:10.1037/0033-2909.125.2.276. 
Friedman, H. S., \& Kern, M. L. (2014). Personality, well-being, and health. The Annual Review of Psychology, 65(January), 719-742. doi:10.1146/ annurev-psych-010213-115123.

Graham, C., \& Soumya, C. (2012). Gender and well-being around the world. Gender and well-being around the world. International Journal of Happiness and Development, 1(2), 212-232. doi:10.1504/ IJHD.2013.055648.

Greenstein, T. N. (2016, 21 August). Gender, marital status and life satisfaction: A cross-national study. Paper presented at the annual meetings of the American Sociological Association, Seattle. doi:10.1186/s13756-016-0144-1.

Guo, L., Baruch, Y., \& Russo, M. (2017). Work resources and civic engagement: Benefits to employee physical and mental health. Journal of Vocational Behavior, 100(2017), 56-66. doi:10.1016/j. jvb.2017.02.007.

Ha, S. E., \& Kim, S. (2013). Personality and subjective well-being: Evidence from South Korea. Social Indicators Research, 111(1), 341-359. doi:10.1007/s11205012-0009-9.

Harris, K., English, T., Harms, P. D., Gross, J. J., \& Jackson, J. J. (2017). Why are extraverts more satisfied? Personality, social experiences, and subjective well-being in college. European Journal of Personality, 186(31), 170-186. doi:10.1002/per.2101.

Himawan, K. K. (2019). Either i do or i must: An exploration of the marriage attitudes of Indonesian singles. Social Science Journal, 56(2), 220-227. doi:10.1016/j. soscij.2018.07.007.

Himawan, K. K., Bambling, M., \& Edirippulige, S. (2017). Modernization and singlehood in Indonesia: Psychological and social impacts. Kasetsart Journal of Social Sciences, $x x x$ (October), 1-8. doi:10.1016/j. kjss.2017.09.008.
Himawan, K. K., Bambling, M., \& Edirippulige, S. (2018). What does it mean to be single in Indonesia? Religiosity, social stigma, and marital status among never-married Indonesian adults. SAGE Open, 8(3), 1-9. doi: $10.1177 / 2158244018803132$.

Hoorn, V. A. (2007, 2-3 April). A short introduction to subjective well-being: Its measurement, correlates and policy uses. Prepared for the international conference. University of Rome 'Tor Vergata', Italy. https://www.oecd.org/site.

Hudson, J. (2006). Institutional trust and subjective well-being across the EU. Kyklos, 59(1), 43-62. doi:10.1111/j.14676435.2006.00319.x.

Jang, S. N., Kawachi, I., Chang, J., Boo, K., Shin, H. G., Lee, H., \& Cho, S. il. (2009). Marital status, gender, and depression: Analysis of the baseline survey of the Korean Longitudinal Study of Ageing (KLoSA). Social Science and Medicine, 69(11), 1608-1615. doi:10.1016/j. socscimed.2009.09.007.

Jones, G. W., Bunnell, T., \& Yeo, V. (2010, January). Changing marriage patterns in Asia (Asia Research Institute Working Paper No. 131). doi:10.2139/ ssrn.1716533.

Khodarahimi, S. (2015). The role of marital status in emotional intelligence, happiness, optimism and hope. Journal of Comparative Family Studies, 46(3), 351372. doi:10.3138/jcfs.46.3.351.

Kristoffersen, I. (2018). Great expectations: Education and subjective wellbeing. Journal of Economic Psychology, 66(April), 64-78. doi:10.1016/j. joep.2018.04.005.

Kuroki, M. (2011). Does social trust increase individual happiness in Japan? The Japanese Economic Review, 62(4), 444-459. doi:10.1111/j.14685876.2011.00533.x. 
Lim, C., \& Putnam, R. D. (2010). Religion, social networks, and life satisfaction. American Sociological Review, 75(6), 914-933. doi:10.1177/0003122410386686.

Lucas, E. R. (2018). Exploring the associations between personality and subjective wellbeing. In E. Diener, S. Oishi, \& L. Tay (Eds.), Handbook of well-being. Salt Lake City, UT: DEF Publishers, pp. 1-15.

Michalos, A. C. (2017). Education, happiness and wellbeing. Social Indicators Research, 87(3), 347-366. doi:10.1007/s11205-0079144-0.

Ngamaba, K. H., Panagioti, M., \& Armitage, C. J. (2017). How strongly related are health status and subjective well-being ? Systematic review and meta-analysis. European Journal of Public Health, 1-7. doi:10.1093/eurpub/ckx081.

Okulicz-Kozaryn, A. (2010). Religiosity and life satisfaction across nations. Mental Health, Religion and Culture, 13(2), 155169. doi:10.1080/13674670903273801.

OECD (Organisation for Economic Co-operation and Development). (2018). Marriage and divorce rates definitions. http://www. oecd.org/els/family/database.htm.

Retnaningsih, U. O. (2013). Indonesian educated unmarried career women: Gender inequality, discrimination, and prejudices. Asia Women, 29(1).

Richmond, P., \& Roehner, B. M. (2016). Effect of marital status on death rates. Part 1 : High accuracy exploration of the Farr Bertillon effect. Physica A: Statistical Mechanics and Its Applications, 450, 748767. doi:10.1016/j.physa.2015.12.136.

Richmond, P., \& Roehner, B. M. (2017). Impact of marital status on health. Physica A: Statistical Mechanics and Its Applications, 486, 542-553. doi:10.1016/j. physa.2017.05.079.
Robards, J., Evandrou, M., Falkingham, J., \& Vlachantoni, A. (2012). Marital status, health and mortality. Maturitas, 73(4), 295299. doi:10.1016/j.maturitas.2012.08.007.

Rosifah, S. N., Nuryakin, C., \& Handalusia, V. (2019). Islamic precepts for marital happiness in Indonesia: The role of religiousity and spouse's characteristics. International Journal of Business and Society, 20(S1), 19-28.

Situmorang,A. (2007). Staying single in a married world. Asian Population Studies, 3(3), 287 304. doi:10.1080/17441730701746433.

Stock, A. W., Okun, M. A., \& Witter, A. R. (1985). Marital status and subjective wellbeing: A research synthesis. Journal of Marriage and Family, 47(4), 947-953. doi:10.2307/352338.

Stone, A. A., Schwartz, J. E., Broderick, J. E., \& Deaton, A. (2010). A snapshot of the age distribution of psychological wellbeing in the United States, 107(10), 6-11. doi:10.1073/pnas.1003744107.

Strauss, J., Witoelar, F., \& Sikoki, B. (2016). User's guide for the Indonesia family life survey, Wave 5 Volume 2 (WR-1143/2NIA/NICHD). California, CA: RAND Corporation.

Striessnig, E. (2015). Too educated to be happy? An investigation into the relationship between education and subjective wellbeing. Laxenburg, Austria.

Sujarwoto, S., Tampubolon, G., \& Pierewan, A. C. (2017). Individual and contextual factors of happiness and life satisfaction in a low middle income country. Applied Research in Quality of Life, 13(4), 927945. doi:10.1007/s11482-017-9567-y.

Tatangelo, A. G., Mccabe, M., \& Szoeke, C. (2017). Gender, marital status and longevity. Maturitas. doi:10.1016/j. maturitas.2017.03.002. 
US Census Bureau. (2016). Divorce statistics in the United States and California. https:// www.census.gov/newsroom/facts-forfeatures/2016/cb16-ff18.html.

Veenhoven, R. (2006). How do we assess how happy we are?. In A. K. Dutt \& B. Radcliff (Eds.), Happiness, economics and politics: Towards a multi-disciplinary approach. Northampton: Edward Elgar Publishing, pp. 45-69. doi:10.4337/9781849801973.

Veenhoven, R. (2009). Life is getting better: Societal evolution and fit with human nature. Social Indicators Research, 97(1), 105-122. doi:10.1007/s11205009-9556-0.

Veenhoven, R. (2015). Happiness : History of the concept. In J. Wright (Ed.), International Encyclopedia of Social \& Behavioral Sciences ( $2^{\text {nd }}$ ed., Vol. 10). Amsterdam: Elsevier, pp.521-525. doi:10.1016/B9780-08-097086-8.03086-5.
Veenhoven, R. (2016). What we have learnt about happiness. In F. Maggino (Ed.), $A$ life devoted to quality of life. Switzerland: Springer International Publishing, pp. 151-172. doi:10.1007/978-3-31920568-7.

Weinhold, D., \& Chaloupka, F. J. (2017). Smoking status and subjective well-being. Tobacco Control, 26(2), 195-201. doi:10.1136/ tobaccocontrol-2015-052601.

Winkelmann, L., \& Winkelmann, R. (1998). Why are the unemployed so unhappy? Evidence from panel data. Economica, 65(257), 1-15. doi:10.1111/14680335.00111.

Yap, S. C. Y., Anusic, I., \& Lucas, R. E. (2012). Does personality moderate reaction and adaptation to major life events? Evidence from the British household panel survey. Journal of Research in Personality, 46(5), 477-488. doi:10.1016/j.jrp.2012.05.005. 